\title{
Climate Politics and the Crisis of the Liberal International Order
}

\section{Felipe Leal Albuquerque*}

\begin{abstract}
The election of Donald Trump brought disarray to the climate change regime. The changes in what was up to then a promoter of the liberal international order (LIO) exacerbated existing tensions while creating new ones. This paper investigates how that challenge impacted the behaviours of Brazil, China and the European Union (EU) by comparatively analysing their dissimilar positions with respect to three indicators before and after Trump's coming into power. These indicators are individual pledges and climate-related policies; approaches to climate finance; and the principle of common but differentiated responsibilities and respective capabilities (CBDR-RC). The analysis first shows how the US started eroding the broader LIO and the climate change regime to then delve into the behaviours of the three respective key players concerning climate talks. I sustain that the EU, despite its inner divisions, is already counteracting Washington, whereas China is combining a pro-status quo position based on a rhetorical condemnation of the United States. Brazil, in turn, had a transition towards a climate-sceptic government, shifting from being a cooperative actor to abdicating hosting the COP25.
\end{abstract}

Keywords: climate change; multilateralism; environment; UNFCCC; European Union; China; Brazil.

\section{Introduction}

Since its inception, the climate change regime has evolved inconsistently. Dynamics of conflict and cooperation have permeated negotiations and involved a growing number of topics such as mitigation, adaptation, loss and damage, capacity building, technology transfer, and climate finance. Clashes have mainly centred on the principle of common but differentiated responsibilities and respective capabilities (CBDR-RC), on which the distribution of climate burden between states was based. Guiding the text of the 1992 United Nations Framework Convention on Climate Change (UNFCCC), the meaning of CBDR-RC was later adapted in the 2015 Paris Agreement. According to the text, the phrase 'in the light of different national circumstances' made reference to the voluntary national* Institute of Social Sciences of the University of Lisbon (ICS-UL), Lisbon, Portugal; felipelra@gmail.com.
ORCID iD 0000-0003-1261-7158. 
ly determined contributions (NDCs) and diluted the strict differentiation between developed and developing countries (United Nations 2015: 5).

The outcome of the $21^{\text {st }}$ Conference of the Parties (COP) to the UNFCCC was the least common denominator in the ambition to hold the increase in the global average temperature to well below $2^{\circ} \mathrm{C}$ and to pursue efforts to limit the temperature increase to $1.5^{\circ}$ $\mathrm{C}$ above pre-industrial levels. Similar to the Convention, the Paris Agreement was born without formal enforcement measures, as it mostly relied on pledge and review mechanisms, naming and shaming strategies of compliance and a system of climate accountability (Keohane and Oppenheimer 2016; Selin 2016). Although being considered by many as the realistic way to move forward, the NDCs enabled sovereignty claims, surpassing the traditional division of annex-I and non-annex-I parties (Streck, Keenlyside and Unger 2016). ${ }^{1}$ The agreement reflected a world in which multilateral cooperation was already being questioned.

Shortly after entering into force, the outcome of the COP-21 was at risk due to changes in the United States of America (USA), which was, by that time, one of the major promoters of the liberal international order (LIO) and guarantor of its condition of being 'easier to join and harder to overturn' (Ikenberry 2015: 453). ${ }^{2}$ In particular, the election of Donald Trump brought disarray to the climate arena, affecting the viability of the Paris Agreement and providing support to sceptics who consider climate change a hoax, as is the case with some groups in Brazil and the European Union (EU).

On the one hand, this challenge exacerbated the regime's inner tensions, legitimizing allegations that the main accords governing climate change erode national sovereignty and institutionalize a state that favours countries like China and India. Central to that is the idea that CBDR-RC has been ill operationalized, allowing large emitters of greenhouse gases (GHG) to free ride and obtain artificial comparative advantages while making use of an anachronistic developing condition.

On the other hand, responses to the threat posed by the USA involved the rejection of claims that the Paris Agreement should be discontinued and the decision to step up climate action and/or reinforce the pillars of the regime. Parties like China and the EU - not to mention subnational governments in the USA and private actors - pledged to enhance commitments, progress with emissions cuts and support climate finance mechanisms.

Although much has been written about recent developments in the climate realm, especially about the Paris Agreement and its implementation (Bodanski 2016; Falkner 2016), much is still needed with respect to how transformations in specific countries impact climate negotiations and provoke subsequent reactions. Furthermore, looking into the interrelations between multilateral regimes like climate change and the broader liberal order proves even more important in current times.

Considering the mentioned dynamics, this paper analyses how changes in an up to then guarantor of the LIO prompted reactions and affected the behaviour of other major stakeholders in the issue-area of climate change. The first section describes changes in the USA and consequences to the wider international system and to the climate change regime. I also present categories of behaviour that might account for the reactions of Brazil, 
China and the EU. The second section delves into the behaviours of these countries and regional bloc until the election of Trump with regard to individual pledges, positions on climate finance, and views on CBDR-RC. The third section considers the same indicators to trace whether and how these players altered their conducts after the transition in the USA. I conclude by mentioning that the ongoing and unresolved disruption process prompted some players to respond to the threat while others only reinforced it.

\section{Changes in the USA and their consequences}

This section is divided into two parts: the domestic shifts in the USA and their impacts on the LIO as a whole, and the more specific consequences for issue-areas like climate change.

\section{Domestic transformations and broader systemic impacts}

Donald Trump was elected in November 2016 as a consequence of a series of unresolved crises occurring not only in the USA, but also in the broader LIO. In that context, existing tensions were amplified and novel ones were created due to the combination of an anti-globalist and a populist rhetoric with the decision to downplay and renegotiate the terms of American multilateral engagement. The USA increasingly opted for a selective approach to global governance, which Patrick (2015) defined as multilateralism à la carte, and Morse and Keohane (2014), as contested multilateralism.

Although this trend is not exclusive to Trump's era, it is now gaining worrying contours. How much harm Trump's foreign policy brought to the stability and continuation of the LIO is still unknown, but its impacts are visible. The disbelief in international organizations, many of which are facing protracted deadlocks, is accompanied by open and systematic disregard for the qualitative dimension of multilateralism (Ruggie 1992). Like-minded countries are pursuing similar paths, which risks turning the existing regimes into mere forums for utilitarian political exchanges.

Indeed, challenges to the LIO were already in motion, as exemplified by the crises in Georgia and Ukraine, which infringed the principles of non-intervention and the prohibition of the threat to use force; NATO's contested intervention in Libya and the further denial of the norm of responsibility to protect (R2P); the Syrian and Yemeni wars and the inobservance of humanitarian law and human rights law; and the election of strongmen in countries like Russia, Turkey, and India, leading some to suggest a return to great power politics (Mearsheimer 2018). Although countries like the USA have questioned and infringed, from time to time, the fundamental norms and values making the LIO, they are now actively seeking to undermine it.

The tide turned in favour of populist movements in European countries like the United Kingdom, Hungary, Poland and Italy, as well as in places like Brazil, Mexico and the Philippines. In a 2018 speech to the UN General Assembly, for example, Trump urged nations to reject globalism and embrace patriotism, avoiding initiatives that could limit national sovereignty. In addition, the White House threatened to cut funding to the UN 
as a whole, to organs such as the World Health Organization (WHO), the UN Women, the UN High Commissioner for Human Rights, the UN Relief and Works Agency for Palestine Refugees, not to mention to peacekeeping and humanitarian initiatives (Samarasinghe 2018).

The visibility of Trump's refutation of the LIO appears in how the USA is interacting with specific regimes. In topics such as nuclear non-proliferation, migration, human rights, trade, health, and climate change, his administration has combined words and deeds, scaling down American contributions and refusing to comply. As mentioned by Peterson (2018: 40), 'the ideological basis on which the USA supported and bolstered the post-war liberal order is now contested, probably as never before since the end of the Second World War.'

In the trade regime, the Trump administration repeatedly blocked the appointment of judges to the Appellate Body of the World Trade Organization (WTO), affecting its dispute settlement system and the resolution of trade controversies. In mid-2018, the USA withdrew from the UN Human Rights Council (BBC 2018). Later that year and alongside Israel, Hungary, Czech Republic and Poland, it voted against the voluntary Global Compact for Safe, Orderly and Regular Migration (Reuters 2018). Several European countries later decided not to adopt the accord, contradicting the European Commission's position. Only the USA and Hungary voted against the Global Compact on Refugees, a non-binding agreement backed by 181 states (United Nations 2018). In the same vein, the USA and Israel left UNESCO. Furthermore, the USA retreated from the bilateral Intermediate-Range Nuclear Forces Treaty (INF) and left Iranian nuclear deal negotiations, causing severe setbacks to the non-proliferation regime. Lastly, Trump authorized sanctions against International Criminal Court officials and, amid the coronavirus pandemic, announced that the USA would withdraw from the WHO.

Questions multiply about whether we are heading towards 'minilateral' relations in which forum shopping and ad hoc coordination become the norm (Naim 2009), leading to a plethora of non-binding agreements functioning on a strictly voluntary basis and being dependent on state sovereignty; to a multilateral system characterized by relative gains, if not zero-sum games; to the fragmentation of regional blocs and the retrieval of unilateralism, nationalism and protectionism; to a world essentially marked by cost-benefit bilateral relations (Stokes 2018). That scenario could also lead to the continuation of the LIO without its original principles like the support for democracy together with the rise of authoritarian powers like China (Duncombe and Dunne 2018), or to the demise of the LIO as we know it.

Bringing more complexity to the current scenario, positive views remain and reinforce the resilience of the ongoing order (Alter 2017). The Paris Agreement, the Global Compact for Safe, Orderly and Regular Migration, the Global Compact on Refugees and the adoption of the Sustainable Development Goals symbolize this continuity. Ikenberry (2018: 23) reminds us that the liberal project has faced crises and dilemmas worse than the present ones; yet, for him, the reform of multilateral forums would need to accommodate more diversity and manage the expectations of rising powers, which are supposed 
to assume more responsibilities. Likewise, Kahler (2018) argues that even in light of a disruptive US administration, adverse trends can be countered by an enlarged coalition involving multinational companies, non-governmental organizations (NGOs) and interested states.

\section{Impacts on the climate change regime}

The climate change regime best exemplifies the mentioned tensions between unilateralism and multilateralism, resilience and change, shared governance and the defence of sovereignty. In no other arena has the Trump administration acted so dramatically as an antagonizing force, sending mixed signals reflecting unresolved domestic clashes between ministries, federal and subnational governments, the Executive and the Legislative. Once in power, he shifted national policies and the US position towards climate matters.

Even considering that the USA had been a laggard on environmental matters since the late 1980s, with its Senate later blocking the ratification of the Kyoto Protocol, its role had recently been positive. The implementation of the Clean Development Mechanism and the series of bilateral meetings prior to the COP-21, for instance, respectively contributed to engage developing countries and pave the way for the Paris Agreement. Moreover, the presidency of Barack Obama (2009-early 2017) demonstrated a willingness to enhance national efforts, as was the case of the Clean Power Plan (CPP), which hoped to cut carbon emissions by 32\% from 2005 levels by 2030; the Climate Action Plan (CAP); and the Mid-Century Strategy for Deep Decarbonization, which expected reductions of $80 \%$ or more below 2005 levels by 2050. Although lacking ambition, the country's NDC presented an economy-wide target of reducing GHG emissions by $26 \%-28 \%$ to below 2005 levels in 2025, including emissions from land use, land use change and forestry (LULUCF). This represented a clear improvement in addition to USA advances in the 2009 COP-15 in Copenhagen.

With Trump, federal climate policy faced financial cuts and open hostility by the president, who announced replacements for the CAP and the CPP, proposed freezing vehicle efficiency standards after 2020 and coal subsidies, decided not to enforce regulations to limit HFC emissions, allowed methane leaks from oil and gas production to continue, and discredited climate science. Additionally, his administration failed to submit climate action reports to the UNFCCC and deleted references to climate change from the Environmental Protection Agency website (Volcovici 2017). The reversion of public policies affected the ability of the USA to achieve its pledges (Galik, DeCarolis and Fell 2017).

Trump's actions also included the termination of the NDC's implementation and a halt in contributions to multilateral development banks (MDBs), to bilateral development assistance related to climate change, as well as to financial mechanisms such as the Green Climate Fund (GCF) (Thwaites 2018). Whereas Obama pledged US $\$ 3$ b to the GCF, having disbursed a third of that until the end of his second mandate, Trump ceased further support (Green Climate Fund 2020). Funding for the Global Environment Facility (GEF), 
the Montreal Protocol Multilateral Fund, the UNFCCC, and the Intergovernmental Panel on Climate Change (IPCC) was also threatened (Gupta 2018).

In a clear strike at multilateralism, Trump declared that the USA would leave the 'disadvantageous' and 'unfair' Paris Agreement in order to 'protect America and its citizens' and stop complying with 'the draconian financial and economic burdens' of the agreement (United States 2017: 3). ${ }^{3}$ When making the statement, he announced that the USA could renegotiate the deal in case it served America's interests. If other parties accepted his bargain, principles like CBDR-RC and pledge and review mechanisms could be renegotiated, which could bring even more uncertainty to already beleaguered talks (Zhang et al. 2017).

In spite of these attacks, the climate change regime has demonstrated resilience, with talks continuing at a slow pace. Among the reasons therefor are the role of subnational governments and civil society actors, which recurrently emphasize the importance of dealing with the topic and press governments to assume more responsibilities (Betsill 2017); the work of the UN and its secretary-general in stressing the need for cooperative solutions, while making climate change remain at the top of the international agenda; the timing of the Paris Agreement and the attempts of the USA to exert leadership during Obama's administration; the fact that climate change has risen to the agenda of the Security Council in recent years, being more and more associated with peace and security matters (Sindico 2007); and the interconnections between climate change and other multilateral arenas like trade, finance, food security, migration, human rights and peace and security, that form 'regime complexes' (Keohane and Victor 2011: 7).

\section{Reactions to Trump: categories of behaviour}

The recent changes in US foreign policy are perceived in distinct ways and lead to different reactions. I discuss three major responses, which are later compared with the behaviours of China, the EU and Brazil in the climate change regime.

Firstly, parties that are already dissatisfied with the LIO and also nurturing anti-globalist views now have more incentives to question its normative and operational components. They can replicate US behaviour, following similar practices; develop new types of opposition to the LIO, such as the creation of alternative institutions; advance proposals to further undermine multilateral regimes; or simply provide rhetorical support to the USA.

Secondly, governments might appear indifferent, not following nor opposing US foreign policy. This in-between reaction can happen since states might not want to assume the costs of challenging the hegemon and consequently favour the broader LIO. In times of friends and foes, opting for a moderate course of action might be crucial, in particular for smaller developing states.

Thirdly, countries benefiting from the status quo and considering the USA a threat are expected to oppose its actions. That resistance behaviour is expected of developed powers like the EU and large developing states such as China, as they can tolerate the costs of balancing the USA. These contending actors can opt to participate more actively than before, partly compensating the damage brought about by Washington (Fehl and Thimm 2019). 
Beyond that, they can deepen multilateral institutionalization, which can occur through the creation of new rules requesting more commitments or novel institutions aimed at enhancing engagement in a specific issue-area whose goal is to increase interdependence, making it harder for spoilers to act. This represents a step further from the previous behaviour, as countries would not only compensate for the USA, but would also act to amplify overall multilateral engagement.

Instead of encouraging more institutionalization, resisting states can simply favour the maintenance of the rules of the game while rhetorically condemning the USA. This type of behaviour is however different from the behaviour of indifference, as states openly criticize the initiatives of spoilers. These countries might endorse existing rules and norms because, after conducting a cost-benefit analysis, they perceive that the status quo brings greater advantages than otherwise. Alternatively, they might actually believe in the importance of maintaining the LIO for its values and goals. In light of the recent challenges to multilateralism, simply complying with previously defined commitments can also be seen as a form of resistance.

Having said that, I compare the behaviours of the EU, China and Brazil in the climate change regime before and after the aforementioned political transition in the USA. By doing so, I can more accurately analyse whether and how Trump's administration prompted changes in these players' multilateral conducts. The two countries and the EU were chosen because they rank among the world's most responsible for annual carbon emissions, with China ranking $1^{\text {st }}$, the EU $3^{\text {rd }}$, and Brazil $7^{\text {th }}$ in several rankings. Among the reasons for this selection were their historical involvement in the regime; the fact that they have distinct views on the division of responsibilities embodied in the principle of CBDR-RC; their different stances towards topics like mitigation, adaptation and climate finance; and the fact that, unlike the EU, China and Brazil were not part of Kyoto's annex-I.

Whereas in Brazil and the EU subnational actors exert relatively more influence over foreign policy formulation than in China, that high number of voices can complicate the definition of multilateral positions. Furthermore, it is important to notice that the EU has a singular type of 'actorness', as it shares competences on climate matters with its member states. As explained by Pavese and Torney (2012), EU engagement in the regime does not replace legal commitments undertaken individually by member states. Compliance, therefore, is a shared responsibility. As the EU needs to surpass internal divisions prior to multilateral negotiations and annual COPs, its 'mandate to act becomes limited to positions internally agreed'; which, however, does not prevent the EU from 'formulating its own approach' to the regime (Pavese and Torney 2012: 130-131).

The analysis is based upon three indicators: individual pledges, visible in each party's NDC and domestic policies and plans, views on CBDR-RC, and approaches to climate finance, which can involve funds like the GCF and the GEF, but also MDBs and SouthSouth cooperation projects. The indicators illustrate the degree to which these parties are willing to accept more obligations or hoping to keep the status quo, which is associated with the behaviour of resistance, or helping to undermine the regime, by replicating America's conduct. 
These three indicators were chosen not only because they reflect the parties' broader views towards how the regime should function (i.e. their readings on the principle of CBDR-RC), but also the main topics being currently discussed in climate talks. While NDCs and domestic policies and plans reveal how states deal with mitigation, adaptation, loss and damage and capacity building, their approaches to climate finance involve both the domestic and multilateral levels of analysis.

In relation to this, I opted for a diachronic exploration of how the behaviours of Brazil, China, and the EU changed after Trump took office. I am not claiming causality nor saying that because of Trump the three players altered their conducts, as that would require indepth within-case analyses and specific methodologies like process tracing. Although environmental regimes are dynamic and highly sensitive to contextual factors (Young 2011), the linkages with Trump's administration may only be indirect. Therefore, I searched for possible traces of change in their foreign policies on climate change after November 2016, which relates to the mentioned categories of behaviour and might reveal the intention to compensate for the USA or support its policies. The possible reasons for these changes will be discussed in the coming sections yet are not the main concern of this article. Bearing in mind the three indicators, I look for climate-related initiatives developed before and after November 2016 in Brazil, China, and the EU, possible shifts in official rhetoric of their leaders, and increase/decrease in disbursements to multilateral climate finance mechanisms and domestic funds. To substantiate the indicators, I resort to official documents, data and publications from MDBs, newspapers and secondary literature.

\section{Brazil, China and the EU before Trump}

This section reviews the policies of Brazil, China and the EU before the political transition in the USA. It takes into account the three indicators substantiating the analysis: individual pledges, approaches to climate finance, and views towards CBDR-RC.

\section{Brazil}

When it comes to individual pledges, Brazil was the only large developing state on the path to the COP-21 to present in its NDC economy-wide absolute targets for emissions reductions. These range from 37\% in 2025 to $43 \%$ in 2030 below 2005 levels, representing a way forward in relation to the pledge for the COP-15. For Paris, Brazil communicated that it would eliminate illegal logging by 2030; restore and reforest 12 million hectares; increase the share of biofuels in the energy mix to $18 \%$; boost the share of renewables to $45 \%$; and expand the use of renewables other than hydropower in the power supply to at least 23\% (Brazil 2015). Brazil's negotiators expected to make the country to be seen as a reliable and responsible actor. However, as explained by Basso (2019: 16), the NDC baseline was presented the year when deforestation peaked. Besides that, pledges for specific sectors demonstrated a lack of ambition. 
Brazil's NDC is supported by national policies and plans developed or updated during the centre-left presidencies of Lula da Silva (2003-2010) and Dilma Rousseff (2011-2016). The National Climate Change Plan of 2008, for instance, had several measures to curb carbon emissions, later being part of the 2009 National Climate Change Law (PNMC), the first such law enacted by a non-OECD state. In the following year, 2010, Brazil established a low-carbon agriculture plan (ABC), followed by the 2015 National Commission and National Strategy for Reducing Emissions from Deforestation and Forest Degradation (REDD+), the 2016 National Adaptation Plan, and the 2017 National Biofuels Policy.

Although Brazil achieved progress in tackling illegal logging - especially in the period between 2005 and 2012, it was never fully controlled. Deforestation returned to grow between 2013-2015 to then surge in 2016 (Viola and Franchini 2018). Environmental budget cuts and lack of proper implementation of the 2012 Forest Code, which had been introduced by the Rousseff's administration, accentuated during the centre-right presidency of Michel Temer (2016-2018).

Regarding Brazil's approach to climate finance, its NDC places the country in an intermediate position between providers and beneficiaries of funding for climate-related activities (Brazil 2015: 3). Brazil is often backed by bilateral partners, the GEF and MDBs, receiving payments for projects in the areas of adaptation, mitigation, capacity building, clean energy, and REDD+. Its NDC also includes possible South-South cooperation projects in the sectors of forest monitoring systems, biofuels capacity-building, and capacity building for national communications.

Brazil's view on CBDR-RC has become more moderate. Brazilian negotiators have traditionally defended the respect for CBDR-RC given that it appears in the UNFCCC and the Kyoto Protocol, reminding that the annex-I parties should financially contribute to support their non-annex-I peers. At least since the 2007 COP-13 in Bali, and due to a rise in their share of global emissions, large developing countries have been pressured to assume additional responsibilities. In light of these developments, at the 2014 COP-20 in Lima, Brazil presented the idea of concentric circles. According to the proposal, CBDR-RC would be operationalized in the Paris Agreement primarily through a differentiation in the types of NDCs and the level of effort expected, with a view to demonstrate that developed countries are effectively taking the lead. It intended to maintain the regime's normative foundations while adapting its operational provisions to current power shifts (Albuquerque 2019). ${ }^{4}$

\section{China}

On the road to the COP-21, in its NDC China presented the commitment to peak economy-wide carbon emissions by 2030 at the latest, lower carbon intensity by $60 \%-65 \%$ below 2005 levels by 2030, and secure a $20 \%$ share of renewable energy in total primary energy demand in 2030. Although China is expected to meet its pledges ahead of time, it has not sufficiently implemented policies to curb non-CO2 emissions. Also, its conditional NDC target creates uncertainty, as it depends on the country's GDP growth. 
China's domestic policies aim to reduce the consumption of coal, which accounts for the greater proportion of China's primary energy supply, and expand the use of natural gas, hydro, wind, solar, and nuclear power. This is the case of the National Action Plan on Climate Change, the Energy Development Strategy Action Plan (2014-2020), the 20152020 Action Plan on the Efficient Use of Coal, the Action Plan of Industries Addressing Climate Change (2012-2020), the Strategy for Energy Production and Consumption Revolution (2016-2030), and the $13^{\text {th }}$ Five Year Plan (2016-2020). Besides shutting down coalbased power plants, China is now responsible for the greatest share of global investments in renewables. ${ }^{5}$

On climate finance, China's NDC reflects the notion that developed powers should continue providing 'new, additional, adequate, predictable and sustained financial support to developing countries for their enhanced actions' (China 2015: 18). ${ }^{6}$ China also voiced the interest of 'further strengthening South-South cooperation on climate change' (China 2015: 16) as part of a wider strategy to increase Chinese-led South-South cooperation. In 2012, for instance, its Ministry of Ecology and Environment and the UN Environment Programme (UNEP) signed the China Trust Fund with annual disbursements of US $\$ 2 \mathrm{~m}$. The first phase went from 2013 to 2015, developed 18 projects and had the goal to promote capacity building activities in developing countries (UNEP 2018). Furthermore, in 2014 China announced the US\$3.1b South-South Climate Change Fund to assist developing countries within and outside its immediate region (Steiner 2017).

China's views on CBDR-RC have been similar to Brazil's, at least until the COP-20. Since the COP-13, Beijing and Brasília have accepted voluntary targets, but emphasized the need for developed powers to take the lead. Throughout the years, the two countries have underscored the need for negotiations to reflect differentiation, the nationally determined nature of contributions and flexibility for developing countries. Difference was nevertheless visible at the COP-20, when Brazil set forth the concept of concentric circles. China, accompanied by India, voiced against new categorizations of countries, dynamic interpretations, and self-differentiation, expressing concern over attempts to close the responsibility gap between developed and developing countries in climate finance (IISD 2014). Its views on CBDR-RC exposed stricter and more traditional interpretations on the principle (Blaxekjaer and Nielsen 2015).

The Communist Party affirmed that China would adhere to the principles of equity and CBDR-RC and urged 'developed countries to fulfil their obligations under the convention to take the lead in substantially reducing their emissions and to provide support of finance, technology and capacity building to developing countries' (China 2015: 16). That perspective was also visible in China's bilateral meetings prior to the COP-21. They not only helped to pave the way to Paris, but also reinforced the notion that the Chinese would stick to the traditional division between developed and developing countries. The expression 'in light of different national circumstances', which appears in the 2014 US-China Joint Announcement on Climate Change, demonstrates that emphasis (Belis et al. 2015). 


\section{The European Union}

The EU has been one of the key players in climate governance, pushing forward a group of policies and plans that later inspired the development of similar measures in other countries and regions (Oberthür and Kelly 2008). The 2005 EU Emissions Trading System (ETS), for instance, is the first and largest emissions trading system, covering around $45 \%$ of the EU's GHG emissions. The third phase of the ETS (2013-2020) implemented a single EU-wide cap in place of the previous systems of national caps. Enacted in legislation in 2009, the 2020 Climate \& Energy Package set three key targets: a reduction of $20 \%$ in GHG emissions from 1990 levels, 20\% of EU energy coming from renewables, and 20\% improvement in energy efficiency. ${ }^{7}$ Currently, EU emissions were reduced by $22 \%$ between 1990 and 2017, while its GDP grew by 58\%. Its commitments are nevertheless still rated 'insufficient' (Climate Action Tracker 2019).

For the COP- 15 , the EU pledged to reduce its emissions unconditionally by $20 \%$ below 1990 levels and committed to scale up its emissions cut to 30\% if other major economies accepted more responsibilities. Pledges were strengthened in 2012, with the European Climate Adaptation Platform, and in 2014, with the 2030 Climate \& Energy Framework, which was the basis for the EU's NDC and had targets to reduce GHG emissions by at least $40 \%$ below 1990 levels, reach at least 32\% share for renewable energy, and at least 32,5\% improvement in energy efficiency. ${ }^{8}$ For the COP-21, the EU and member states communicated an economy-wide binding target of at least $40 \%$ reduction in carbon emissions by 2030 below 1990 levels.

Throughout the regime's evolution, the EU has had considerable leverage in discussions on climate finance, 'promising funding to developing countries for actions to mitigate and adapt to climate change in exchange for supporting the EU's vision' (Parker, Karlsson and Hjerpe 2017: 247). For its weight, the EU has the ability to 'veto' unwanted discussions on climate finance.

From 2013 to 2016, the total climate finance from EU institutions and member states increased from US $\$ 9.5 \mathrm{~b}$ to US $\$ 20.2 \mathrm{~b}$ with Germany, France, the United Kingdom, Spain, the Netherlands and Sweden taking the lead (Dejgaard and Appelt 2018). In addition, of the ten largest financial contributors to the Special Climate Change Fund, five are EU member states (World Bank 2020). The bloc asserts that its official development assistance to developing countries is increasingly including climate action, but numbers accounting for that are inaccurate (Dejgaard and Appelt 2018).

The EU also established mechanisms to finance sustainable growth. The Multiannual Financial Framework 2014-2020, for example, devoted around €3.4b to the Programme for the Environment and Climate Action (LIFE). The Cohesion Fund supported projects on renewable energy and cleaner transportation and the NER 300 pooled together about $€ 2$.1b for low-carbon energy projects. A common criticism is that the data that measures European finance for mitigation is better and more transparently tracked than the data for adaptation (Eichler et al. 2017).

As for the EU's considerations on CBDR-RC, it has recurrently complied with Kyoto's binding emission reduction targets. The EU has pressured China, India, Brazil and others 
to enhance efforts, seeing the division in annex-I and non-annex-I countries detrimental to itself (Albuquerque 2019). Prior to the COP-21, European negotiators considered the NDCs as a possible way to operationalize CBDR-RC and reflect the current state of things. Their expectations on the developing states nevertheless continued, as NDCs were required to ensure fairness and reflect 'evolving realities' (IISD 2014: 4).

\section{Brazil, China and the EU after Trump}

This section shows whether and how the climate-related policies and multilateral engagement of Brazil, China and the EU shifted following the establishment of the new government in the USA.

\section{Brazil}

Brazilian domestic policies and plans receded during the presidency of Michel Temer, who remained in power for two years after Trump's election. The country had $7.536 \mathrm{~km}^{2}$ of forests cleared in the Amazon between August 2017 and July 2018, an increase of 8,5\% over the previous year (Brazil 2020). ${ }^{9}$ Furthermore, the Temer administration made concessions to the agribusiness sector, legalizing squatted lands in the Amazon and harming the rights of indigenous peoples, approved measures to reduce federal conservation units and national parks, tried to abolish a vast Amazon reserve to attend the interests of the mining sector, and cut funding for the environmental sector (Phillips 2018). Apart from that, Brazil ratified the Paris Agreement in September 2016 and offered to host the COP25 , somehow trying to maintain the 'core of the Brazilian climate myth', acting as a country exercising a leadership role in UNFCCC negotiations (Franchini and Viola 2019: 14).

Prospects deteriorated during the 2018 presidential campaign, when loss of forest cover soared almost $50 \%$ in anticipation of looser environmental regulations and in reason of the victory of far-right candidate Jair Bolsonaro (Maisonnave, 2018). In the period between August 2018 and July 2019, deforestation in the Amazon rose sharply to 10.129 $\mathrm{km}^{2}$, a 34\% increase from the previous year and the highest level since 2008 (Brazil 2020). ${ }^{10}$ During his first year in power, Bolsonaro threatened to make the Ministry of the Environment part of the Ministry of Agriculture, Livestock and Food Supply to then diminish its functions vis-à-vis other governmental bodies, attacked environmental agencies, advanced anti-indigenous measures, weakened enforcement of environmental laws, praised land-grabbers and mining groups, and withdrew Brazil's offer to host the COP-25. His anti-globalist foreign minister argued that global warming is a Marxist plot (Watts 2018) and his environment minister said climate change was a secondary issue (Bilenky, Fernandes and Watanabe 2018). Mimicking Trump, Bolsonaro declared that he would pull Brazil out of the Paris Agreement. He later backed down on plans for fears of commercial retaliation from European trade partners, which threatened to reject the EU-MERCOSUR deal. ${ }^{11}$

When it comes to climate finance, Brazil's Temer continued receiving international support, mainly for REDD+ actions. In 2017, Norway cut forest protection payments to 
the Amazon Fund by more than $50 \%$ in response to a surge in deforestation, but in December donated new resources, together with the German Development Bank, to support projects in the region. As for the South-South cooperation provided by Brazil, as appears in its NDC, the Ministry of the Environment partnered with the Brazilian Cooperation Agency (ABC) to promote the REDD+ focused Brazilian Program for South-South Cooperation on Climate Change and Forests (Brazil 2017) whose implementation was sluggish, especially after recent bureaucratic shifts. Also, under Temer, the country made a contribution to the GEF (World Bank 2017). With Bolsonaro in power, even if not attributed to his administration, Brazil was the first country to receive financial aid from the GCF for the successes in halting deforestation in the period 2014-2015. In 2019, Bolsonaro changed the governance structure of the Amazon Fund, which led Norway and Germany to suspend payments to the fund and accuse Brazil of breaking the agreement to reduce deforestation.

Regarding Brazil's views on CBDR-RC, its multilateral activism and defence of the principle diminished. It is already visible that the Bolsonaro administration harmed the country's reputation not only due to its decision to withdraw the offer to host the COP-25 and threaten to leave the Paris Agreement, but also for the fact that the Ministry of the Environment lost significance and became a conservative and anti-environmental force (Viola and Gonçalves 2019). In addition, the views of the foreign minister contradict Brazil's traditional engagement in the regime, which curtails the work of negotiators.

\section{China}

Following Trump's election, China did not change the general orientation of its domestic policies and plans nor its intentions to take climate leadership (Hilton and Kerr 2017). As mentioned, its most substantive initiatives - the National Action Plan, the Action Plan on the Efficient Use of Coal, and the $13^{\text {th }}$ Five Year Plan (2016-2020) - cut across several years and are not contingent on American foreign policy. More and more, China endeavours to shift its development model towards an economy based on low-carbon advanced technology (He 2016), or what its negotiators call an 'eco-civilization' (IISD 2016: 12). That guidance was part of the $19^{\text {th }}$ National Congress of the Communist Party in 2017.

The Made in China 2025 plan, launched in 2015, goes in the same direction, pointing out that emerging industries like green energy and electric vehicles are key for a future China (National Development and Reform Commission 2017). In 2017, Beijing announced a novel cap and trade system, indicating that it could be expanded. Moreover, China tightened air pollution targets and planned to expand the share of renewables in its energy mix. The country, however, registered a rise in coal consumption in 2017, which led to higher emissions, and the reduction of subsidies for solar installations in 2018. China expects to further control the volume of carbon emissions and progressively reduce the use of coal in its $14^{\text {th }}$ Five Year Plan (2021-2025) (Neuweg and Stern 2019).

Concerning climate finance, China continued with the second phase of the China Trust Fund for the period from 2016 to 2018. Other projects that started before the shifts 
in the USA gained ground, as happens with the Belt and Road Initiative (BRI), which will receive funds from institutions like the Asian Infrastructure and Investment Bank (AIIB) and the Silk Road Fund (UNDP 2016). In 2017, the United Nations Development Programme (UNDP) and the National Development and Reform Commission signed an action plan to strengthen the relevance of the sustainable development goals in the BRI. Two years later, the Belt and Road Initiative International Green Development Coalition (BRICG) was launched with the support of the UN Environment Programme (UNEP) expecting to improve the environmental safeguards of the BRI. The increasing leading role of China in climate matters is also visible in initiatives alongside the UNDP on rehabilitation and reconstruction in the Caribbean and in the creation of the China South-South Cooperation Assistance Fund (Steiner 2017).

With Trump in power, China continued with its traditional views on CBDR-RC, which is exemplified by its resistance to deliver funds to the GCF. Albeit willing to assume more responsibilities both domestically and in South-South cooperation initiatives, the Chinese are against undertaking binding obligations and expect to keep China's status as a developing country in place. By maintaining this orientation, the country can still identify itself with the G77 and the BASIC coalition of Brazil, South Africa, India, and China, while demanding more actions by the former annex-I members.

China's reactions to Trump are more clearly seen in the rhetorical level and in negotiations in and out of the UNFCCC. During the 2017 World Economic Forum in Davos, for example, president Xi Jinping claimed parties should meet the challenges of climate change, adhere to multilateralism and abide by the rules. Directly addressing Trump, he mentioned that 'the Paris Agreement is a hard-won achievement which is keeping with the underlying trend of global development. All signatories should stick to it instead of walking away' (Financial Times 2017: 2). Likewise, the Chinese delegation stated, in the 2017 COP-23 in Bonn, that the Paris Agreement has built 'irreversible momentum' (IISD 2017: 29). In 2019, Chinese Foreign Ministry spokesperson Geng Shuang said that 'China regrets that the USA began the process to withdraw from the Paris Agreement (...) we hope the USA will act proactively and responsibly instead of pulling out' (China 2019).

\section{The European Union}

The development of new climate-related policies and plans in the EU continued after the political transition in the USA, as is the case with the fourth phase of the ETS (2021-2030) and the launching of the Climate-ADAPT Strategy 2019-2021. Furthermore, in 2018, the European Council revised future targets for renewables and energy efficiency part of the 2030 Climate \& Energy Framework. Like the USA under Obama, the EU also forwarded a long-term strategy expecting to turn Europe climate-neutral by 2050 (European Commission 2018a). The European Parliament and the mayors of the ten largest European cities embraced the goal of net zero emissions.

Although progress is noticeable, the EU suffers from internal setbacks and political crises over 'how ambitious the EU should be in its climate policies' (Averchenkova et al. 
2016: 56). The bloc portrays itself as a unified voice advocating for the transition to greener economies, but several of its members have contending views, a trend that has recently become more evident with the ascension of Eurosceptic and nationalist parties. The case of Poland is illustrative, as it is still much dependent on coal, which led part of its bureaucracy to question the Paris Agreement and the costs of reforming the EU carbon market (Sengupta et al. 2017). While some countries are phasing out coal and replacing this source of energy for natural gas, others - i.e. Poland, Germany, Italy and the Netherlands - have built new coal power plants (Olivier, Schure and Peters 2017). Lack of consistency was also visible in 2017, when the EU's investments in renewables fell to the lowest level since 2006 to recover again in 2018 (BloombergNEF 2019). In late 2019, the European Commission announced the European Green Deal, with a view to achieve climate neutrality by 2050, and proposed the first European Climate Law. As part of the deal, the EU proposed a Just Transition Mechanism and a Just Transition Fund. The bloc expects to cut carbon emissions to at least 50\% and towards 55\% by 2030 (European Commission 2019).

Internal divisions are also visible in European disbursements to climate finance mechanisms. Germany, France, the United Kingdom, Italy, the Netherlands, Spain, Sweden, Denmark and Norway pledged the greater part of the EU's contribution to climate funds, a disposition not shared by states such as Hungary and Poland. This separation suggests two distinct environmental agendas developing within the union, but does not yet affect the bloc's image as a whole, which remains positive. That was visible during the 2018 COP-24 in Katowice, when several EU members increased commitments to the GCF and to the World Bank Group's Adaptation Fund. More than 70\% of the contributions to the Adaptation Fund come from Germany, Sweden, Spain, Belgium, Italy and France. Of the top ten donors, seven are EU members. Concerning the GCF, France, Germany, Sweden and Norway affirmed in 2019 that they would substantially increase their commitments, partially compensating for the USA (Green Climate Fund 2020). ${ }^{12}$

On the regional level, the EU is implementing new funding schemes, as happens with the Innovation Fund and the Action Plan on Financing Sustainable Growth. Announced in 2018, the Innovation Fund may amount to $10 \mathrm{~b} €$ from 2020 to 2030 to fund low-carbon technologies and processes in energy intensive industries, carbon capture and utilization, construction and operation of carbon capture and storage, innovative renewable energy generation, and energy storage. ${ }^{13}$ Adopted in 2018 by the European Commission, the Action Plan bridges the Paris Agreement with the 2030 Agenda for Sustainable Development.

With the adoption of the Paris Agreement, the EU's views on CBDR-RC were focused on issues like the conduction of the Talanoa Dialogue and how to harmonize parties' contributions to the Global Climate Action Agenda. This more pragmatic approach created perceptions that the bloc was too centred on mitigation. During the COP-24 and opposing the interest of many least developed and developing countries, for instance, the EU resisted mentioning CBDR-RC in the discussions on further guidance in relation to adaptation communication (IISD 2018).

Beyond the more theoretical discussions on CBDR-RC, the EU hopes to do more in the fight against climate change. In a direct reference to the USA and to Trump's campaign 
slogan, the president of the European Commission Jean-Claude Juncker affirmed in 2017 that 'against the collapse of ambition in the United States, Europe will ensure to make our planet great again. It is the shared heritage of all humanity' (European Commission 2017). The same intention appears in a 2018 report from the European Commission (European Commission 2018b: 12).

\section{Conclusions}

The article demonstrates that changes in an until-then guarantor of the LIO prompted reactions and affected the behaviours of Brazil, China and the EU when it comes to climate matters. These linkages were nevertheless indirect and more visible in the discursive level. The assaults by the Trump administration were seen as a leadership opportunity for China and the EU but their responses were mostly conditioned by long-running policy orientations. In the case of Brazil, reversals in national climate-related policies not only followed shifts in domestic politics, but also echoed a general resentment with the LIO headed by the USA.

Considering the analysis prior to Trump's election, Brazil developed an array of successful policies and plans most centred on REDD+, also showing the intention to contribute to the global effort to tackle climate change. After Trump's election, changes were already underway during the presidency of Temer, as national policies contradicted Brazil's multilateral engagement and affected its pledges. That inconsistency was visible in Brazil's offer to host the COP-25, which was later undone during Bolsonaro's presidency, as prospects worsened and domestic setbacks intensified and were substantiated by anti-globalist views. It is possible to say that his administration gave rhetorical support to the USA and, for threatening to leave the Paris Agreement, reversing policies and cutting domestic funding, it attempted to replicate American behaviour. That being said, Brazil continues partaking in the regime, which suggests that its negotiators and other domestic actors resist changing the country's disposition to dialogue.

In the case of China, its pledges and domestic plans have been focused on mitigation and exhibit greater continuity than Brazil's. China maintained long-term policies that are not contingent on the shifts seen in the USA. It is also complicated to assume any direct relation between Trump's administration and China's disposition to fund South-South cooperation projects on climate change. Beijing's behaviour of resistance is better seen at the discourse level when it called upon the USA to fulfil its obligations and keep the LIO on going. By and large, China's 'minimalist position' is characterized by the combination of preserving the status quo with the reluctance to openly balance the USA. As the USA retreats, more expectations are placed on China for it to assume more responsibilities and a leadership position on climate change (Zhang 2019).

The EU also has long-term regional pledges and policies mostly designed to mitigation that cannot be attributed to the domestic changes in the USA. However, the bloc is a heavyweight on climate finance and is now devoting even more attention to climate finance mechanisms, which shows the intention of some of its members to compensate for 
American positions. All in all, the EU appears to be moving from underpinning the status quo to start compensating the USA. It is also important to mention that the EU's overall role should be decoupled from the views of its members. Whereas Hungary and Poland are displaying rhetorical support to the USA in a move similar to Brazil's Bolsonaro, states like France, Germany and Norway as well as the European Commission, the European Parliament and the European Council are nurturing the intention to counterbalance the USA.

Up to now, US foreign policy under Trump affected but could not decisively undermine the climate change regime. Among other things, the long-lasting policies of China and the EU and the role of subnational governments and civil society actors avoided broader disruption, which is more clearly seen in regimes such as nuclear non-proliferation and trade. If the USA continues to oppose the state of things, there is also the possibility that we could start seeing closer cooperation on climate matters between China and the EU (Belis and Schunz 2013) or a trilateral engagement with India (Jotzo, Depledge and Winkler 2018), a small group of actors able to shape climate diplomacy. As the European Commission defines it, the bloc wants to 'build alliances with the likeminded' (European Commission 2019: 2). That intention was clear when, at the 2020 EU-China summit, the president of the European Council Charles Michel argued that engaging and cooperating with China is both an opportunity and a necessity.

Finally, this article demonstrates that the goal of tracing causal claims is not well suited for comparative analyses, requiring further studies using within-case methods like process tracing. As it tackles a very recent topic, more data and analytical distance are required for better comprehension of ongoing developments.

\section{Notes}

1 Discussing the nature of the NDCs, Streck, Keenlyside and Unger (2016:11) affirm that 'the challenge was to find both a flexible interface between the bottom-up, dynamic commitments of countries and the static group-level agreement and, at the same time, a legal formula that would reconcile the genuinely voluntary nature of NDCs with a set of legally binding provisions on the NDC process.' This tension is visible in some parts of the Paris Agreement, for instance, in article 13, which touches upon a 'transparency framework'. The text states that it should be 'non-intrusive, non-punitive and respectful of national sovereignty' (United Nations 2015: 16).

2 I define the $\mathrm{LIO}$ as the collection of multilateral regimes governing interstate interactions since the aftermath of the Second World War in addition to their relations with non-state actors. Separately, regimes involve a group of principles, norms, rules, and decision-making procedures enabling and restricting states' actions in specific issue-areas (Krasner 1983). At the same time, these norms-infused and rule-based architectures are affected by the agency of individual states, which composes a co-constitutive process leading to an erratic evolution of pre-existing parameters. Ruggie (1982) calls attention to the centrality of democracy, human rights and free trade in the making and keeping of the LIO. More recently, several authors theorized novel ways of approaching order and ordering, for example, Acharya and Buzan (2010) and Tickner and Waever (2009).

3 At the time, only Nicaragua and Syria were not parties to the Paris Agreement. Article 28 determines that the earliest possible date for effective withdrawal is on 4 November 2020, a day after the next US election.

4 The concentric circles is a three-layer proposal, in which the inner circle is comprised of parties having quantified absolute limitation or reduction targets in relation to a baseline year in their NDCs. It was thought for the Annex I parties, which should continue to take most of the burden. The second circle 
contains states whose emission limitation or reduction targets relate to all sectors of their economies, but not absolute ones. Large developing powers would fit into this intermediate category, but they could also voluntarily adopt absolute targets. The third circle referred to least developed countries with emission targets aimed at some sectors of their economies (Albuquerque 2019).

For a comprehensive list of policies and plans, see: National Development and Reform Commission (2017).

6 That 'legalist' view is underpinned by article 4.1 (c), 4.3, 4.5 and 4.7 of the UNFCCC (United Nations 1992).

7 Under the 2020 package, the Effort Sharing legislation established binding annual emission targets for member states.

8 Numbers refer to revised targets.

9 In the same period, deforestation in the Cerrado biome amounted to $6.634 \mathrm{~km}^{2}$, a reduction of $11 \%$ compared to the year before.

10 Deforestation in the Cerrado biome fell 2,26\%, but increased $15 \%$ in federal conservation units.

11 France, Ireland and Luxembourg warned that they would reject the deal for Brazil's inaction on Amazon wildfires. Finland, holding the EU chairmanship at the time, called for the EU to evaluate banning Brazilian beef from its markets. Afterwards, the parliaments of Austria and the Netherlands rejected the accord.

12 For EU's contributions to the GEF, see World Bank (2017).

13 The European Fund for Strategic Investments (EFSI) also channels resources to reduce the EU's environmental footprint.

\section{References}

Acharya, A and B Buzan (eds). 2010. Non-Western International Relations Theory: Perspectives on and Beyond Asia. New York: Routledge.

Albuquerque, F L. 2019. 'Coalition Making and Norm Shaping in Brazil's Foreign Policy in the Climate Change Regime.' Global Society 33(2): 243-261.

Alter, K J. 2017. 'The Future of International Law. iCourts Working Paper Series 101 [online]. At https://papers.ssrn.com/sol3/papers.cfm?abstract_id=3015177 [Accessed on 27 February 2020]

Averchenkova, A et al. 2016. 'Climate Policy in China, the European Union and the United States: Main Drivers and Prospects for the Future - In-depth Country Analyses.' Grantham Research Institute on Climate Change and the Environment [online]. At http://www.lse.ac.uk/GranthamInstitute/ wp-content/uploads/2016/11/Averchenkova-et-al_2106-in-depth-country-analysis-docx.pdf [Accessed on 11 March 2020]

Basso, L. 2019. 'Brazilian Energy-related Climate (In)action and the Challenge of Deep Decarbonization'. Revista Brasileira de Política Internacional 62(2): 1-21.

$B B C$ [online]. 2018. 'US Quits 'Biased' UN Human Rights Council'. 20 June. At https://www.bbc. com/news/44537372 [Accessed on 21 February 2020]

Belis, D and S Shunz. 2013. 'China and the European Union: Emerging Partners in Global Climate Governance?' Environmental Practice 15(3): 190-200.

Belis, D et al. 2015. 'China, the United States and the European Union: Multiple Bilateralism and Prospects for a New Climate Change Diplomacy.' Carbon \& Climate Law Review 9(3): 203-218.

Betsill, M M. 2017. 'Trump's Paris Withdrawal and the Reconfiguration of Global Climate Change Governance.' Chinese Journal of Population Resources and Environment 15(3): 189-191.

Bilenky, T, T Fernandes and P Watanabe. 2018. 'Climate Change is a Secondary Issue, Says Future Minister of Environment.' Folha de S. Paulo [online]. 10 December. At https://www1.folha.uol. 
com.br/internacional/en/brazil/2018/12/climate-change-is-a-secondary-issue-says-future-minister-of-environment.shtml [Accessed on 15 August 2020]

Blaxekjaer, L O and T Nielsen. 2015. 'Mapping the Narrative Positions of New Political Groups under the UNFCCC.' Climate Policy 15(6): 751-766.

BloombergNEF [online]. 2019. Clean Energy, Investment Trends, 2018. 16 January. At https://data. bloomberglp.com/professional/sites/24/BNEF-Clean-Energy-Investment-Trends-2018.pdf [Accessed on 11 March 2020]

Bodanski, D. 2016. 'The Legal Character of the Paris Agreement.' Review of European, Comparative, and International Environmental Law 25(2): 142-150.

Brazil [online]. 2015. Intended Nationally Determined Contribution. 28 September. At http://www4. unfccc.int/submissions/INDC/Published\%20Documents/Brazil/1/BRAZIL\%20iNDC\%20english\%20FINAL.pdf [Accessed on 3 March 2020]

. 2017. Brazilian 'Program for South-South Cooperation in Climate Change and Forests'. At http://redd.mma.gov.br/images/conaredd/programforsscinclimatechangeandforests-executivesummary-EN-Nov17-COP23-RP.pdf [Accessed on 7 March 2020]

2020. TerraBrasilis PRODES (Desmatamento). 14 August. At http://terrabrasilis.dpi. inpe.br/ [Accessed on 14 August 2020].

China [online]. 2015. Enhanced Actions on Climate Change: China's Intended Nationally Determined Contributions. 30 June. At https://www4.unfccc.int/sites/ndcstaging/Pages/Home.aspx [Accessed on 7 March 2020]

2019. Foreign Ministry Spokesperson Geng Shuang's Regular Press Conference on November 5, 2019. 5 November. At https://www.fmprc.gov.cn/mfa_eng/xwfw_665399/s2510_665401/ t1713475.shtml [Accessed on 15 August 2020]

Climate Action Tracker [online]. 2019. EU. 2 December. At https://climateactiontracker.org/countries/eu/fair-share/ [Accessed on 14 August 2020]

Dejgaard, H P and J Appelt. 2018. 'An Analysis of the Climate Finance Reporting of the European Union.' ACT Alliance EU [online]. At https://actalliance.eu/wp-content/uploads/2018/04/Analysisof-the-climate-finance-reporting-of-the-EU.pdf [Accessed on 11 March 2020]

Duncombe, C and T Dunne. 2018. 'After Liberal World Order'. International Affairs 94(1): 25-42.

Eichler, L et al. 2017. 'Assessing the State-of-play of Climate Finance Tracking in Europe.' Trinomics [online]. At https://trinomics.eu/wp-content/uploads/2017/07/State-of-play-of-European-climatefinance-tracking-published-6-July-2017.pdf [Accessed on 1 April 2020]

European Commission [online]. 2017. President Juncker Delivers State of the Union Address 2017. 13 September. At https://ec.europa.eu/commission/news/president-juncker-delivers-state-unionaddress-2017-2017-sep-13_en [Accessed on 10 March 2020]

2018a. A Clean Planet for All. Brussels. 28 November. At https://eur-lex.europa.eu/ legal-content/EN/TXT/PDF/?uri=CELEX:52018DC0773\&from=EN [Accessed on 9 March 2020]

. 2018b. Action Plan: Financing Sustainable Growth. 3 August. At https://eur-lex.europa. eu/legal-content/EN/TXT/?uri=CELEX:52018DC0097 [Accessed on 11 March 2020]

. 2019. The European Green Deal. 11 December. At https://ec.europa.eu/info/sites/info/ files/european-green-deal-communication_en.pdf [Accessed on 14 August 2020] 
Falkner, R. 2016. 'The Paris Agreement and the New Logic of International Climate Politics.' International Affairs 92(5): 1107-1125.

Fehl, C and J Thimm. 2019. 'Dispensing with the Indispensable Nation?'. Global Governance: A Review of Multilateralism and International Organizations 25(1): 23-46.

Financial Times [online]. 2017. 'Xi Jinping Delivers Robust Defence of Globalisation at Davos'. 17 January. At https://www.ft.com/content/67ec2ec0-dca2-11e6-9d7c-be108f1c1dce [Accessed on 8 March 2020].

Franchini, M A and E Viola. 2019. 'Myths and Images in Global Climate Governance, Conceptualization and the Case of Brazil (1989-2019)'. Revista Brasileira de Politica Internacional 62(2): 1-21.

Galik, C S, J F DeCarolis and H Fell. 2017. 'Evaluating the US Mid-century Strategy for Deep Decarbonization amidst Early Century Uncertainty.' Climate Policy 17(8): 1046-1056.

Green Climate Fund [online]. 2020. Resource Mobilization. 12 August. At https://www.greenclimate.fund/about/resource-mobilisation [Accessed on 12 August 2020].

Gupta, Joydeep. 2018. 'Green Funds Dry Up for Developing Countries'. Earth Journalism Network [online]. 27 June. At https://earthjournalism.net/stories/green-funds-dry-up-for-developing-countries [Accessed on 28 February 2020]

He, J-K. 2016. 'Global Low-carbon Transition and China's Response Strategies'. Advances in Climate Change Research 7(4): 204-212.

Hilton, I and O Kerr. 2017. 'The Paris Agreement: China's 'New Normal' Role in International Climate Negotiations.' Climate Policy 17(1): 48-58.

IISD. 2014. SB 40 Final. Earth Negotiations Bulletin 12(598): 1-36.

2016. COP-22 Final. Earth Negotiations Bulletin 12(689): 1-30.

2017. COP-23 Final. Earth Negotiations Bulletin 12(714): 1-33.

2018. COP-24 Final. Earth Negotiations Bulletin 12(747): 1-34.

Ikenberry, J G. 2015. 'The Future of the Liberal World Order.' Japanese Journal of Political Science 16(3): 450-455.

2018. 'The End of the Liberal International Order?'. International Affairs 94(1): 7-23.

Jotzo, F, J Depledge and H Winkler. 2018. 'US and International Climate Policy under President Trump'. Climate Policy 18(7): 813-817.

Kahler, M. 2018. 'Global Governance: Three Futures'. International Studies Review 20(2): 239-246.

Keohane, R O and M Oppenheimer. 2016. 'Paris: Beyond the Climate Dead End through Pledge and Review?'. Politics and Governance 4(3): 142-151.

Keohane, R O and D G Victor. 2011. 'The Regime Complex for Climate Change'. Perspectives on Politics 9(1): 7-23.

Krasner, S D (ed). 1983. International Regimes. Ithaca: Cornell University Press.

Maisonnave, F. 2018. 'Bolsonaro's Deforestation of the Amazon Has Already Begun.' Climate Home News [online]. 14 November. At https://www.climatechangenews.com/2018/11/14/bolsonaros-deforestation-amazon-already-begun/ [Accessed on 6 March 2020]

Mearsheimer, J J. 2018. The Great Delusion: Liberal Dreams and International Realities. New Haven and London: Yale University Press. 
Morse, J C and R O Keohane. 2014. 'Contested Multilateralism'. The Review of International Organizations 9(4): 385-412.

Naim, M. 2009. 'Minilateralism: The Magic Number to Get Real International Action. Foreign Policy [online]. At https://foreignpolicy.com/2009/06/21/minilateralism/ [Accessed on 27 February 2020]

National Development and Reform Commission [China]. 2017. China's Policies and Actions for Addressing Climate Change. Beijing.

Neuweg, I and N Stern. 2019. 'China's $14^{\text {th }}$ Plan, Sustainable Development and the New Era'. Grantham Research Institute on Climate Change and the Environment [online]. At https://www. lse.ac.uk/granthaminstitute/wp-content/uploads/2019/05/Chinas-14th-plan-sustainable-development-and-the-new-era.pdf [Accessed on 11 August 2020].

Oberthür, S and C R Kelly. 2008. 'EU Leadership in International Climate Policy: Achievements and Challenges.' The International Spectator: Italian Journal of International Affairs 43(3): 35-50.

Olivier, J G J, K M Schure and J A H W Peters. 2017. Trends in Global CO2 and Total Greenhouse Gas Emissions: 2017 Report. PBL Netherlands Environmental Assessment Agency, The Hague.

Parker, C F, C Kalrsson and M Hjerpe. 2017. 'Assessing the European Union's Global Climate Change Leadership: From Copenhagen to the Paris Agreement.' Journal of European Integration 39(2): 239252.

Patrick, S. 2015. 'Multilateralism à la Carte: The New World of Global Governance'. Valdai Discussion Club 22 [online]. At https://www.cfr.org/blog/multilateralism-la-carte-new-world-global-governance [Accessed on 22 February 2020]

Pavese, C B and D Torney. 2012. 'The Contribution of the European Union to Global Climate Change Governance: Explaining the Conditions for EU Actorness.' Revista Brasileira de Politica Internacional 55(special edition): 125-143.

Peterson, J. 2018. 'Present at the Destruction? The Liberal Order in the Trump Era.' The International Spectator: Italian Journal of International Affairs 53(1): 28-44.

Phillips, D. 2018. 'Brazil Records Worst Annual Deforestation for a Decade.' The Guardian [online]. 24 November. At https://www.theguardian.com/environment/2018/nov/24/brazil-records-worst-annual-deforestation-for-a-decade [Accessed on 6 March 2020]

Reuters [online]. 2018. 'UN Formally Approves Global Migration Pact Opposed by US.' 19 December. At https://www.reuters.com/article/us-migrants-un-idUSKCN1OI26H [Accessed on 21 February 2020]

Ruggie, J G. 1982. 'International Regimes, Transactions and Change: Embedded Liberalism in the Post-war Economic Order'. International Organization 36(2): 379-415.

1992. 'Multilateralism: The Anatomy of an Institution.' International Organization 45(3): 561-598.

Samarasinghe, N. 2018. 'Can the UN Survive Trump?' Chatham House [online]. December \& January 2018/19. At https://www.chathamhouse.org/publications/twt/can-un-survive-trump [Accessed on 27 February 2020]

Selin, H. 2016. 'Climate Finance and Developing Countries: The Need for Regime Development.' GEGi Working Paper 009 - 10/2016: 1-14. 
Sengupta, S et al. 2017. 'As Trump Exits Paris Agreement, Other Nations Are Defiant.' The New York Times [online]. 1 June. At https://www.nytimes.com/2017/06/01/world/europe/climate-paris-agreement-trump-china.html [Accessed on 8 March 2020]

Sindico, F. 2007. 'Climate Change: A Security (Council) Issue?'. Carbon \& Climate Law Review 1(1): 29-34.

Steiner, A. 2017. 'South-South Cooperation on Climate Change.' UNDP [online]. 15 November. At https://www.undp.org/content/undp/en/home/news-centre/speeches/2017/south-south-cooperation-on-climate-change.html [Accessed on 8 March 2020]

Stokes, D. 2018. 'Trump, American Hegemony and the Future of the Liberal International Order' International Affairs 94(1): 133-150.

Streck, C, P Keenlyside and M Unger. 2016. 'The Paris Agreement: A New Beginning.' Journal for European Environmental \& Planning Law 13(1): 3-29.

Thwaites, J. 2018. 'US 2018 Budget and Climate Finance: It's Bad, but Not as Bad as You Might Think.' WRI [online]. 23 March. At https://www.wri.org/blog/2018/03/us-2018-budget-and-climate-finance-its-bad-not-bad-you-might-think [Accessed on 4 March 2020]

Tickner, A B and O Waever (eds). 2009. International Relations Scholarship around the World. London and New York: Routledge.

UNDP. 2016. UNDP-China Partnership on South-South and Global Cooperation: 2015 Highlights. Beijing: UNDP China.

UNEP [online]. 2018. Progress Update on South-South Cooperation. 8 November. At https:// wedocs.unep.org/bitstream/handle/20.500.11822/26620/10\%20UN\%20Environment\%20NBO1. SSC\%20Presentation $\% 2007 \% 20 \% 2808 \% 20$ Nov\%202018\%29.pdf? sequence=17\&isAllowed=y [Accessed on 8 March 2020]

United Nations [online]. 1992. United Nations Framework Convention on Climate Change. At https://unfccc.int/resource/docs/convkp/conveng.pdf [Accessed on 14 March 2020]

2015. Adoption of the Paris Agreement. At https://unfccc.int/resource/docs/2015/ cop21/eng/109r01.pdf [Accessed on 27 February 2020]

2018. GA/12107. 17 December. At https://www.un.org/press/en/2018/ga12107.doc. htm [Accessed on 21 February 2019]

United States [online]. 2017. Statement by President Trump on the Paris Climate Accord. 1 June. At https://www.whitehouse.gov/briefings-statements/statement-president-trump-paris-climate-accord/ [Accessed on 26 February 2020].

Viola, E and M Franchini. 2018. Brazil and Climate Change: Beyond the Amazon. New York: Routledge.

Viola, E and V K Gonçalves. 2019. 'Brazil ups and downs in Global Environmental Governance in the $21^{\text {st }}$ Century.' Revista Brasileira de Política Internacional 62(2): 1-10.

Volcovici, V. 2017. 'Trump Administration Tells EPA to Cut Climate Page from Website: Sources.' Reuters [online]. 25 January. At https://www.reuters.com/article/us-usa-trump-epa-climatechange/ trump-administration-tells-epa-to-cut-climate-page-from-website-sources-idUSKBN15906G [Accessed on 26 March 2020] 
Zhang, H. 2019. 'Climate Change Policies of the Trump Administration and China's Response.' In W Wang and Y Liu (eds), Annual Report on China's Response to Climate Change (2017). Springer: Singapore, pp. 27-38.

Zhang, Y-X et al. 2017. 'The Withdrawal of the US from the Paris Agreement and Its Impacts on Global Climate Change Governance.' Advances in Climate Change Research 8(4): 213-219.

Watts, J. 2018. 'Brazil's New Foreign Minister Believes Climate Change is a Marxist Plot.' The Guardian [online]. 15 November. At https://www.theguardian.com/world/2018/nov/15/brazil-foreign-minister-ernesto-araujo-climate-change-marxist-plot [Accessed on 15 August 2020]

World Bank. 2017. Global Environmental Facility Trust Fund (GEF) TF029840. Washington: D.C.

World Bank [online]. 2020. Special Climate Change Fund (SCCF). 13 July. At https://fiftrustee. worldbank.org/en/about/unit/dfi/fiftrustee/fund-detail/sccf [Accessed on 14 August 2020]

Young, O R. 2011. 'Effectiveness of International Environmental Regimes: Existing Knowledge, Cutting-edge Themes, and Research Strategies.' PNAS 108(50): 19853-19860.

\section{About the author}

Felipe Leal Albuquerque holds a Ph.D. in Political Science from the Institute of Social Sciences of the University of Lisbon (ICS-UL), where he was a Marie Curie Fellow. In 2016, he was a visiting doctoral researcher at the German Institute of Global and Area Studies (GIGA) and at the Stellenbosch University. He holds a master's degree in International Relations from the Rio de Janeiro State University (UERJ) and a specialisation in Contemporary International Relations from the Pontifical Catholic University of Rio de Janeiro (PUC-Rio). He worked as a lecturer at the Federal University of Rio de Janeiro (UFRJ) and as a research assistant at Fundação Getúlio Vargas (FGV). 


\section{Políticas Climáticas e a Crise da Ordem Internacional Liberal}

Resumo: A eleição de Donald Trump trouxe desordem ao regime da mudança climática. As mudanças em um promotor da ordem internacional liberal (LIO) exacerbaram as tensões existentes enquanto criavam novas. Este artigo estuda como esse desafio impactou os comportamentos do Brasil, da China e da União Europeia (UE). Faço isso analisando comparativamente as diferentes posições do Brasil, da China e da UE em relação a três indicadores antes e depois da chegada de Trump ao poder: compromissos individuais e políticas relacionadas ao clima, abordagens ao financiamento do clima e ao princípio das responsabilidades comuns porém diferenciadas e respectivas capacidades (CBDR-RC). A análise primeiro mostra como os EUA começaram a corroer a LIO mais amplo e o regime de mudança climática para depois mergulhar nos comportamentos dos três principais atores das negociações climáticas. Eu defendo que a UE, apesar de suas divisões internas, já está contrariando Washington, enquanto a China está combinando uma posição pró-status quo com uma condenação retórica dos Estados Unidos. O Brasil teve uma transição para um governo cético em relação ao clima, passando de um ator cooperativo a um que abdicou de sediar a COP 25.

Palavras-chave: mudança climática; multilateralismo; meio ambiente; UNFCCC; União Europeia; China; Brasil.

Received on 11 May 2020, and approved for publication on 09 December 2020. 